\title{
A Comparative Study of Ingudi phalamajja Lepa and Ananatmul Ghan in The Management of Vyanga (Melasma)
}

\author{
Research Article
}

\section{Shraddha Wake', Vaishali Kuchewar ${ }^{2}$, Prajkta Hagone1*}

\author{
1. PG Scholar, 2. Professor and HOD, Department of Kayachikitsa, \\ Mahatma Gandhi Ayurved College Hospital \& Research Center, Salod, Wardha, Maharashtra
}

\begin{abstract}
The normal color of skin in human is largely due to melanin pigment. Melasma is most common disorder which is related to melanin. It is a human melanogenesis dysfunction that results in localized, chronic acquired hypermelanosis of the skin. In Ayurveda melasma can be correlated with Vyanga because of resemblance of its clinical features. According to Acharya Charak, it is caused due to vitiation of Pitta and Shonita but other Acharyas has depicted it due to the vitiation of Väta and Pitta. This study is aimed to explore the Efficacy of Ingudi Phalmajja lepa with and without internal use of Anantamoola Ghana in Vyanga. Total 43 patients were registered and randomly divided into group A and group B by lottery method. Out of these, 40 patients have completed the treatment. All patients were examined by Wood's Lamp to assess the depth of pigmentation (Dermal/Epidermal).. It is concluded that vyanga is frequent in females than males. It was found in madhyamavastha in which pitta dosha and Rajoguna is predominant. Mostly Centrofacial type of melasma is found in this study which is supported by other studies. Melasma Severity Index is improved in both the groups. Local application of Ingudi phalmajja is found to be effective in the severity of pigmentation. The action of Ingudi phalamajja in hyperpigmentation could not be evaluated. Further study can be conducted to find out the active principle of Ingudi.
\end{abstract}

Key Words: Vyanga, Melasma, Ingudi phalmajja, Ananatmul Ghan.

\section{Introduction}

Now a day, the importance of Beauty and Personality is on the rise. In this aesthetic era, people are getting more and more beauty conscious, so everyone wants beautiful and healthy skin. Due to change in life style and atmosphere, dermatological problems are on high. Beauty of a person is assessed by the complexion and texture of the skin to a great extent. The normal color of skin in human is largely due to melanin pigment. Melasma is most common disorder which is related to melanin. It is a human melanogenesis dysfunction that results in localized, chronic acquired hypermelanosis of the skin. It occurs symmetrically on sun exposed areas of the body and affects especially female.(1) It is accounting for 0.25 to $4 \%$ of the patients seen in Dermatology Clinics in South East Asia, and is the most common pigment disorder among Indians. $(2,3)$ Although women are predominantly affected, men are not excluded from melasma, representing approximately $10 \%$ of the cases. (4) It is rarely reported before puberty. It can affect up to $50-70 \%$ of pregnant women. $(4,5,6$,$) Though the$ etiological factors are unknown but genetic, ethnic (skin type), hormonal and environmental i.e. ultraviolet (UVA and UVB) exposures can be called as major

\section{* Corresponding Author:}

\section{Prajakta Hagone}

PG Scholar, Department of Kayachikitsa,

Mahatma Gandhi Ayurved College Hospital \&

Research Center, Salod, Wardha, Maharashtra. India

Email Id: p6hagone@gmail.com contributing factors. Many modalities of treatment are available, but chances of recurrence are more after discontinuation of the treatment or long-lasting usage of local preparations may produce irritation. $(5,6,7)$ In Ayurveda melasma can be correlated with Vyanga which is described under kshudraroga because of resemblance of its clinical features. According to Acharya Charak, it is caused due to vitiation of Pitta and Shonit(8) but other Acharyas has depicted it due to the vitiation of Vāta and Pitta. $(9,10,11,12,13)$ In Ayurvedic texts, various therapies like Raktamokshan, Siravedha as well as some medicines for internal \& external use are mentioned.

\section{Need of study}

Melasma has a significant impact on appearance causing psychosocial distress, low selfconfidence and decline in quality of life. $(14,15,16,17,18)$ Because of its increasing prevalence and unsatisfactory management, it is needed to discover some herbal preparation to overcome it.

\footnotetext{
Aim

Efficacy of Ingudi Phalmajja lepa with and without internal use of Anantamoola Ghana in Vyanga.

Objectives of the study

1. To evaluate the efficacy of Ingudi phalmajja lepa.

2. To evaluate the efficacy of Ingudi phalmajja lepa with Anantamoola ghana in vyanga.

3. To compare the effecacy of Ingudi phalmajja lepa and Ingudi phalmajja lepa with Anantamoola ghana in vyanga.
} 


\section{Material and Method}

\section{Source of Material}

The Patients were randomly selected from Kayachikitsa OPD of Mahatma Gandhi Ayurved College, Hospital \& Research center, Salod $(\mathrm{H})$, Wardha with the features of Vyanga (Melasma) were selected for the study.

\section{Inclusion criteria}

- Patients of either sex between the age group of 20 50 years.

- Patients presenting with cardinal features of Vyanga are Shyavavarna, Nirujam, Tanu, Mandal (Melasma like thin, painless, blackish/brownish patch on facial skin).

\section{Exclusion criteria}

- Cases of drug induced Melasma.

- Pregnant women

- Patients with known case of Addison's disease, Cushing's syndrome or Nelson's syndrome.

\section{Investigation}

Before commencement of medication, CBC with ESR was done to exclude any infectious condition.

\section{Methodology}

The patients were selected by simple random sampling method irrespective of their sex, religion and occupation. The informed consent was obtained from each patient before participation in the study. Total 43 patients were registered as per the inclusion criteria and randomly divided into group A and group B by lottery method. Out of these, 40 patients have completed the treatment. All patients were examined by Wood's Lamp to assess the depth of pigmentation (Dermal/ Epidermal).

Following treatment was given for both the groups.
- Group A- Ingudi(Balanites aegyptiaca) phalmajja for local application once a day for continuous 90 days. ${ }^{25}$

- Group B-Anantamool (Hemidesmus indicus) Ghana orally $500 \mathrm{mg}$ twice a day with water after meal and local application of Ingudi phalmajja once a day for continuous 90 days. 26

Method of application of Ingudi Phalamajja lepa: Patient was advised first to clean the face properly. Take the Ingudi phalamajja and rub down with cold water on any clean rough surface to make paste in sufficient quantity and apply over the affected area for 20 minutes and then wash the face properly with plain water. This lepa was applied once a day for continuous 90 days.

\section{Assessment Criteria}

The assessment of patient was done on the basis of following MSI score (Melasma severity index) on every $30^{\text {th }}$ day.

Melasma Severity Index score formula

\begin{tabular}{|c|}
\hline $0.4\left(\mathrm{a} \times \mathrm{P}^{2}\right) \mathrm{I}+0.4\left(\mathrm{a} \times \mathrm{P}^{2}\right) \mathrm{r}+0.2\left(\mathrm{a} \times \mathrm{P}^{2}\right) \mathrm{n}$ \\
Where. $\mathrm{a}-$ Area, $\mathrm{P}-$ Pigmentation, I - Left face , $\mathrm{R}-$
\end{tabular}
Right face

The area involved and severity of pigmentation is scored as follows

\begin{tabular}{|c|c|}
\hline Grade & Area Involvement $(\mathrm{A})$ \\
\hline 0 & $<10 \%$ area involved \\
\hline 1 & $11-30 \%$ area involved \\
\hline 2 & $31-60 \%$ area involved \\
\hline 3 & $>60 \%$ area involved \\
\hline
\end{tabular}

\begin{tabular}{|c|c|}
\hline Grade & Pigmentation \\
\hline 0 & No visible Pigmentation \\
\hline 1 & Barely Visible pigmentation \\
\hline 2 & Mild pigmentation \\
\hline 3 & Moderate pigmentation \\
\hline 4 & Sever pigmentation \\
\hline
\end{tabular}

\section{Observation \& Result}

The data obtained was coded and entered into Microsoft Excel Worksheet. The data was analyzed by using frequency distribution, descriptive statistics, analysis of variance, chi-square test and t-statistic with the help of statistical software SPSS 17.0 version and tabulated as below.

Table No. 1 Gender-wise distribution of Patients

\begin{tabular}{|c|c|c|c|}
\hline & \multicolumn{3}{|c|}{ Gender } \\
\cline { 2 - 4 } & Male & Female & Total \\
\hline Group A & $1(5.0 \%)$ & $19(95.0 \%)$ & $20(100.0 \%)$ \\
\hline Group B & $3(15.0 \%)$ & $17(85.0 \%)$ & $20(100.0 \%)$ \\
\hline Total & $4(10.0 \%)$ & $36(90.0 \%)$ & $40(100.0 \%)$ \\
\hline
\end{tabular}

Table No. 2 Age-wise distribution of Patients

\begin{tabular}{|c|c|c|c|c|}
\hline & \multicolumn{3}{|c|}{ Age (in years) } & Total \\
\hline Group A & $20-30$ & $31-40$ & $41-50$ & $20(100.0 \%)$ \\
\hline Group B & $2(10.0 \%)$ & $13(65.0 \%)$ & $5(25.0 \%)$ & $20(100.0 \%)$ \\
\hline Total & $4(20.0 \%)$ & $8(40.0 \%)$ & $8(40.0 \%)$ & $40(100.0 \%)$ \\
\hline
\end{tabular}




\section{Table No. 3 Sharir Prakruti of Patients}

\begin{tabular}{c|c} 
& Kapha pittaj \\
\hline Group A & $1(5.0 \%)$ \\
\hline Group B & $2(10.0 \%)$ \\
\hline Total & $3(7.5 \%)$
\end{tabular}

Shari
Pitta kaphaj
$1(5.0 \%)$
$1(5.0 \%)$
$2(5.0 \%)$

SharirPrakruti

Chi-Square Value $=2.667 \mathrm{P}$ Value $=0.446$ Non Significant.

In the categorization of Sharir prakruti, 52.5\% patients were of Vata pittaj Prakruti and 35\% patients were of Pittavataj prakruti. Comparatively less number of patients were of Kapha Pittaj(7.5\%) and Pitta Kaphaj(5\%) Prakruti.

Table No. 4 Manas Prakruti of Patients

\begin{tabular}{|c|c|c|c|c|}
\hline & \multicolumn{3}{|c|}{ Manas Prakruti } & Total \\
\hline Group A & Satvik & Rajasik & Tamasik & $20(100.0 \%)$ \\
\hline Group B & $6(30.0 \%)$ & $13(65.0 \%)$ & $1(5.0 \%)$ & $20(100.0 \%)$ \\
\hline Total & $11(55.0 \%)$ & $8(40.0 \%)$ & $1(5.0 \%)$ & $40(100.0 \%)$ \\
\hline
\end{tabular}

Chi-Square Value $=2.661 \mathrm{P}$ Value $=0.264$ Non Significant In the classification of Manas prakruti, the patients of Satvik, Rajasik and Tamasikit Prakruti were $42.5 \%, 52.5 \%$ and 5\% respectively.

Table No. 5 Type of Ahara of Patients in Group A \& Group B

\begin{tabular}{|c|c|c|c|}
\hline & \multicolumn{2}{|c|}{ Ahara } & \multirow{2}{*}{ Total } \\
\hline & Satvik & Rajasik & \\
\hline Group A & $9(45.0 \%)$ & $11(55.0 \%)$ & $20(100.0 \%)$ \\
\hline Group B & $9(45.0 \%)$ & $11(55.0 \%)$ & $20(100.0 \%)$ \\
\hline Total & $18(45.0 \%)$ & $22(55.0 \%)$ & $40(100.0 \%)$ \\
\hline
\end{tabular}

Chi-Square Value $=0.001 \mathrm{P}$ Value $=1.00$ Non Significant

Table No.5 shows that the 55\% patients were consuming largely Rajasik ahara and $45 \%$ patients were consuming mostly Tamasik ahara.

Table No. 6 Sun Exposure of Patients

\begin{tabular}{|c|c|c|c|}
\hline & \multicolumn{2}{|c|}{ Sun Exposure } & \multirow{2}{*}{ Total } \\
\hline & Yes & No & \\
\hline Group A & $9(45.0 \%)$ & $11(55.0 \%)$ & $20(100.0 \%)$ \\
\hline Group B & $12(60.0 \%)$ & $8(40.0 \%)$ & $20(100.0 \%)$ \\
\hline Total & $21(52.5 \%)$ & $19(47.5 \%)$ & $40(100.0 \%)$ \\
\hline
\end{tabular}

Chi Square $=0.90 \mathrm{P}$ Value $=0.342$ Non Significant Table no. 6 shows that $52.5 \%$ patients were having history of regular sun exposure and $47.5 \%$ patients had no history of frequent sun exposure.

Table No. 7 Family History of Patients

\begin{tabular}{|c|c|c|c|}
\hline & \multicolumn{2}{|c|}{ Family History } & \multirow{2}{*}{ Total } \\
\hline & Yes & No & \\
\hline Group A & $11(55.0 \%)$ & $9(45.0 \%)$ & $20(100.0 \%)$ \\
\hline Group B & $7(35.0 \%)$ & $13(65.0 \%)$ & $20(100.0 \%)$ \\
\hline Total & $18(45.0 \%)$ & $22(55.0 \%)$ & $40(100.0 \%)$ \\
\hline
\end{tabular}

Chi-Square Value $=1.616$ P Value $=0.204$ Non Significant such history.

Out of 40 patients, $45 \%$ patients were having family history of Melasma and 55\% patients were not having

Table No. 8 Chronicity wise distribution of Patients

\begin{tabular}{|c|c|c|c|}
\hline Duration & Group A & Group B & Total \\
\hline Less than 6 months & $5(12.5 \%)$ & $2(5.0 \%)$ & $7(17.5 \%)$ \\
\hline 6months-3 years & $8(20.0 \%)$ & $10(25.0 \%)$ & $18(45.0 \%)$ \\
\hline 3 years-10 years & $7(17.5 \%)$ & $8(20.0 \%)$ & $15(37.5 \%)$ \\
\hline Total & $20(50.0 \%)$ & $20(50.0 \%)$ & $40(100.0 \%)$ \\
\hline
\end{tabular}

Chi Square $=1.575$ P Value $=0.455$ Non Significant

Analysis of data obtained reveals that majority of the patients $(45 \%)$ were having chronicity of Vyanga between 6 months-3years followed by 37\%, 17.5\% were having 3years- 1year, less than 6 months respectively. 
Shraddha Wake et.al., A study of Ingudi phalamajja Lepa and Ananatmul Ghan in the Management of Vyanga (Melasma)

\section{Table No. 9 Clinical sub-type wise distribution of Patients}

\begin{tabular}{c|c|c|c|}
\hline Sub-type & Group A & Group B & Total \\
\hline Centrofacial & $10(25 \%)$ & $14(35 \%)$ & $24(60 \%)$ \\
\hline Malar & $10(25 \%)$ & $6(15.0 \%)$ & $18(40 \%)$ \\
\hline Mandibular & 0 & 0 & 0 \\
\hline Total & $20(50.0 \%)$ & $20(50.0 \%)$ & $40(100.0 \%)$ \\
\hline
\end{tabular}

The Clinical sub-types of Melasma are divided into Centrofacial, Malar and Mandibular. In this study $60 \%$ and $40 \%$ patients were of centrofacial and malar respectively and no mandibular sub type was observed.

Table No. 10 Dermal/Epidermal classification

\begin{tabular}{c|c|c|c|} 
& Dermal & Epidermal & Total \\
\hline Group A & $7(35.0 \%)$ & $13(65.0 \%)$ & $20(100.0 \%)$ \\
\hline Group B & $11(55.0 \%)$ & $9(45.0 \%)$ & $20(100.0 \%)$ \\
\hline Total & $18(45.0 \%)$ & $22(55.0 \%)$ & $40(100.0 \%)$ \\
\hline
\end{tabular}

Chi Square $=1.62 \mathrm{P}$ Value $=0.203$ Non Significant

The type of Melasma was diagnosed with the help of Wood's lamp. It is found that $45 \%$ patients were of Dermal type and 55\% patients were of Epidermal type.

Table No. 11 Mean MSI Score of Group A

\begin{tabular}{|c|c|c|c|c|c|}
\hline Group A & Mean & S.D. & Std. Error Mean & t-value & P value \\
\hline MSI Score 0 Day & 13.74 & 9.17 & 2.05 & \multirow{4}{*}{11.391} & \multirow[b]{2}{*}{1} \\
\hline MSI Score $30^{\text {th }}$ Day & 10.79 & 6.73 & 1.50 & & \\
\hline MSI Score $60^{\text {th }}$ Day & 5.71 & 4.21 & 0.94 & & $\mathrm{Sin}$ \\
\hline MSI Score $90^{\text {th }}$ Day & 3.15 & 3.74 & 0.83 & & significant \\
\hline
\end{tabular}

The MSI score in Group A was $13.74,10.79,5.71$ and 3.15 on day $0.30^{\text {th }}$, $60^{\text {th }}$ and $90^{\text {th }}$ respectively. Significant difference is observed in the MSI score on 0 day and on $90^{\text {th }}$ day.

Table No. 12 Mean MSI Score of Group B

\begin{tabular}{|c|c|c|c|c|c|}
\hline Group B & Mean & S.D. & Std. Error Mean & t-value & P value \\
\hline MSI Score 0 Day & 17.33 & 12.01 & 2.68 & \multirow{4}{*}{6.263} & \multirow{4}{*}{ Significant } \\
\hline MSI Score $30^{\text {th }}$ Day & 15.04 & 10.49 & 2.34 & & \\
\hline MSI Score $60^{\text {th }}$ Day & 8.65 & 8.20 & 1.83 & & \\
\hline MSI Score $90^{\text {th }}$ Day & 8.65 & 7.89 & 1.76 & & \\
\hline
\end{tabular}

The MSI score in Group B was $17.33,15.04,8.65$ and 8.65 on day $0.30^{\text {th }}, 60^{\text {th }}$ and $90^{\text {th }}$ respectively. Significant difference is observed in the MSI score on 0 day and on $90^{\text {th }}$ day.

Table No. 13 Comparison of Dermal/Epidermal Melasma in Group A

\begin{tabular}{|c|c|c|c|c|c|c|}
\hline \multicolumn{2}{|r|}{ Group A } & Mean & S.D. & Std. Error Mean & $\mathrm{t}$-value & P Value \\
\hline \multirow{2}{*}{ Dermal } & $\begin{array}{l}\text { MSI (Melasma Severity Index) } \\
\text { SCORE } 0 \text { day }\end{array}$ & 17.77 & 10.60 & 4.01 & \multirow[b]{2}{*}{2.930} & \multirow{2}{*}{$\begin{array}{c}0.026 \\
\text { Significant }\end{array}$} \\
\hline & $\begin{array}{l}\text { MSI (Melasma Severity Index) } \\
\text { SCORE 3rd follow up 90th day }\end{array}$ & 5.89 & 5.18 & 1.96 & & \\
\hline \multirow{2}{*}{ Epidermal } & $\begin{array}{l}\text { MSI (Melasma Severity Index) } \\
\text { SCORE } 0 \text { day }\end{array}$ & 11.57 & 7.91 & 2.19 & \multirow{2}{*}{4.793} & \multirow{2}{*}{$\begin{array}{l}0.001 \\
\text { Significant }\end{array}$} \\
\hline & $\begin{array}{l}\text { MSI (Melasma Severity Index) } \\
\text { SCORE 3rd follow up } 90^{\text {th }} \text { day }\end{array}$ & 1.68 & 1.43 & 0.40 & & \\
\hline
\end{tabular}

Table No. 13 shows the comparison of Dermal and Epidermal type of Melasma in Group A. In Dermal type, MSI score was 17.77 on day 0 which was reduced to 5.89 on day $90^{\text {th }}$. In Epidermal type, MSI score was 11.57 on day 0 which was reduced to 1.68 on day $90^{\text {th }}$.In both type of Melasma, significant improvement was observed.

Table No. 14 Comparison of Dermal/Epidermal Melasma in Group B

\begin{tabular}{|c|c|c|c|c|c|c|}
\hline \multicolumn{2}{|r|}{ Group B } & Mean & S.D. & Std. Error Mean & T-value & P Value \\
\hline \multirow{2}{*}{ Dermal } & $\begin{array}{l}\text { MSI( Melasma Severity Index) } \\
\text { SCORE 0th day }\end{array}$ & 19.25 & 13.04 & 3.93 & \multirow[b]{2}{*}{3.092} & \multirow{2}{*}{$\begin{array}{c}0.011 \\
\text { Significa } \\
\text { nt }\end{array}$} \\
\hline & $\begin{array}{l}\text { MSI( Melasma Severity Index) } \\
\text { SCORE 3rd follow up } 90^{\text {th }} \text { day }\end{array}$ & 9.07 & 9.30 & 2.80 & & \\
\hline \multirow{2}{*}{ Epidermal } & $\begin{array}{l}\text { MSI( Melasma Severity Index) } \\
\text { SCORE 0 } 0^{\text {th }} \text { day }\end{array}$ & 14.98 & 10.90 & 3.63 & \multirow{2}{*}{3.860} & \multirow{2}{*}{$\begin{array}{c}0.005 \\
\text { Significa } \\
\text { nt }\end{array}$} \\
\hline & $\begin{array}{l}\text { MSI( Melasma Severity Index) } \\
\text { SCORE 3rd follow up } 90^{\text {th }} \text { day }\end{array}$ & 1.20 & 1.23 & 0.41 & & \\
\hline
\end{tabular}


Table No. 14 shows the comparison of Dermal and Epidermal type of Melasma in Group B. In Dermal type, MSI score was 19.25 on day 0 which was reduced to 9.07 on day $90^{\text {th }}$. In Epidermal type, MSI score was 14.98on day 0 which was reduced to 1.20 on day $90^{\text {th }}$. So in both the types the score was significantly decreased.

Table No. 15 Comparison of Mean MSI Score in Group A \& Group B

\begin{tabular}{|c|c|c|c|c|c|}
\hline & & Mean & S.D. & t-statistic & P value \\
\hline \multirow{2}{*}{ Group A } & 0 day & 13.74 & 9.17 & & 0.001 \\
\cline { 2 - 7 } & $90^{\text {th }}$ day & 3.16 & 3.74 & 5.568 & Significant \\
\hline \multirow{2}{*}{ Group B } & 0 day & 17.33 & 12.01 & 4.933 & 0.001 \\
\cline { 2 - 7 } & $90^{\text {th }}$ day & 5.53 & 7.89 & & Significant \\
\hline
\end{tabular}

The mean MSI score of group A was 13.74 on day 0 which was decreased to 3.16 on $90^{\text {th }}$ day. In Group B also it was decreased from 17.33 to 5.53 . In both the groups, MSI score was significantly decreased indicating the improvement in hyperpigmentation.

\section{Table no 16 Comparison of Mean MSI Score in Group A \& Group B}

\begin{tabular}{|c|c|c|}
\hline MSI score & Number of patients Before Treatment & Number of patients After treatment \\
\hline $0-15$ & 24 & 36 \\
\hline $15-30$ & 12 & 4 \\
\hline $30-55$ & 4 & 0 \\
\hline MSI score & Number of patients Before Treatment & Number of patients After treatment \\
\hline $0-10$ & $19(47.5)$ & $35(87.5 \%)$ \\
\hline $10-20$ & $10(25 \%)$ & $02(5 \%)$ \\
\hline $20-30$ & $06(15 \%)$ & $03(7.5 \%)$ \\
\hline $30-40$ & $05(12.5 \%)$ & 0 \\
\hline
\end{tabular}

\section{Discussion}

Total 43 patients were registered Out of these, 40 patients have completed the treatment. In this study, $90 \%$ patients were female. In other studies also the percentage of female was predominant $(19,20)$ Females are usually utilize different cosmetics. It might be the cause of hyperpigmentation.(21,22) In our study Maximum patients were in the age group of 31-40 years. It is a fertile age group. Use of Oral contraceptive pills might be the contributing factor.(23) This study did not find significant family history of Melasma. But in other studies Family history of melasma was found significant.(24) In the classification of Sharirika prakriti, most of the patients were of vatapittaja \& Pittavataj type indicating the role of Pitta \& Vata in the samprapti of Vyanga. There was no significant difference in the number of patients of satvik \& rajasik prakruti but comparatively the patients of rajasik prakruti were more. In Ayurvedic literature, krodha and shoka are included in the causative factors of vyanga

Most of the patients were having diet predominant in katu (pungent) \& lavan (salty) rasa which can be called as rajasik ahar. It might be the aggravating factor of Pitta \& Vata dosha. In this study, $52 \%$ patients were found to be exposed to sun during their working hours but remaining had no direct exposure. So it is difficult to make any co-relation between sun exposure \& Melasma. The patients were assessed on the basis of MSI score to evaluate the efficacy of trial drugs. The significant improvement was found in group A (Ingudi phala majja lepa) and Group
B (Ingudi phala majja lepa \& Anantmool Ghana orally). In the comparison of both groups, group B showed relatively good score than group A, In both the groups, there was significant improvement in Dermal and Epidermal types of Melasma. In literature, Anatmool is described as having madhur \& tikta Rasa, guru \& snigdha guna, madhur vipaka \& sheet virya. It is also described as varnya. All these characteristics might be responsible to pacify pitta \& Vata which are described as root cause of vyanga. Its varnya property might be helpful to provide normal color to skin. Ingudi is tikta, katu Rasatmaka (predominantly katu rasa) having Ushna Virya, Snigdha and Laghu Guna and Katu Vipak. It balances Vata and Kapha Dosha of Ingudi, it reaches up to the micro channel and liquefies the morbid Dosha due to its qualities like ushna and tikshna. Because of Snigdha property it protects the skin from excessive dryness. It also maintains the normal moisture content of the skin, Snigdha Guna is responsible for Mardava and Varna Prasadana where as Laghu is the property of Agneya Dravya, which in turn are responsible for Prabha, Prakasha, and Varna.

\section{Conclusion}

It is concluded that vyanga is frequent in females than males. It was found in madhyamavastha in which pitta dosha and Rajoguna is predominant. Only sun exposure cannot be called as causative factor because it is found in exposed and unexposed both. Melasma Severity Index is improved in both the groups. Local application of Ingudi phalmajja is found to be 
Shraddha Wake et.al., A study of Ingudi phalamajja Lepa and Ananatmul Ghan in the Management of Vyanga (Melasma)

effective in the severity of pigmentation. The action of Ingudi phalamajja in hyperpigmentation could not be evaluated. Further study can be conducted to find out the active principle of Ingudi.

\section{References}

1. Miot LD, Miot HA, Silva MG, Marques ME. Physiopathology of melasma. An Bras Dermatol. 2009;84:623-635. [PubMed]

2. Corsi H. Chloasma Virginum Periorale. Proc R Soc Med. 1935;28:1169-1169. [PMC free article] [PubMed]

3. Lindsay HC. Chloasma uterinum. Arch Derm Syphilol. 1946;53:58-58. [PubMed]

4. Balkrishnan, R, (2004) Improved Quality of Life with Effective Treatment of Facial Melasma: The Pigment Trial. Journal of Drugs in Dermatology, 3, 377-381.

5. Perez, M.L. (2005) The Stepwise Approach to the Treatment of Melasma. Cutis, 75, 217-222.

6. Victor F (2004) Melasma: A Review. Journal of Cutaneous Medicine and Surgery, 8, 97- http:// dx.doi.org/10.1007/s10227-004-0158-9

7. Torok, H. (2005) Hydroquinone 4\%, Tretinoin $0.05 \%$, Flucinoloneacetonide 0.01\%: A Safe and Efficious 12-Month Treatment for Melasma. Cutis, 75, 57-62

8. Balkrishnan R. et al.Validation of a melasma quality of life questionnaire for the Turkish language: the MelasQoL-TR study. J Dermatolog Treat. 2009;20:95-99. [PubMed]

9. Sitaram B. Bhav Prakash, Chaukhambha Orientila Varanasi.2010 (Madhyan Uttar Khanda)vol II First edition P578

10. Grummer $\mathrm{S}$, et al. Development and validation of a health-related quality of life instrument for women with melasma. Br J Dermatol. 2003;149:572-577. [PubMed]

11. Pandya AG. et al. Melasma in Latina patients: cross-cultural adaptation and validation of a quality-of-life questionnaire in Spanish language. $\mathrm{J}$ Am Acad Dermatol. 2006;55:59-66. [PubMed]

12. Almeida $A$, et al. Validation of a melasma quality of life questionnaire for Brazilian Portuguese language: the MelasQoL-BP study and improvement of QoL of melasma patients after triple combination therapy. $\mathrm{Br} \mathrm{J}$ Dermatol. 2006;156:13-20. [PubMed]

13. Taieb C. et al. Melasma: measure of the impact on quality of life using the French version of Melasool after cross-cultural adaptation. Acta Derm Venereol. 2010;90:331-332. [PubMed]

14. Tripathi R. ed Charak Samhita Volume I, edition 2009, 18/25 Chaukhamba Sanskrit Pratishtan Delhi, p 278

15. Murthy S. ed. Madhava Nidanam (Roga Viniscaya) of Madhavkara, nidan 55/39 Eight edition 2007. Jaikrishnadas Ayurveda series no.69 Chaukhambha Orientila Varanasi,p.181

16. Rao P.S. ed. Vaghbhata's Astang Samgrah Vol III (Uttara Sthana) 36/30 First edition 2009 Krishnadas Ayurveda series no.106 Chowkhamba Krishandas Academy, Varansi; p326.

17. Murthy. K. ed Vaghbhata's Astang Hrdayam volume III (Uttarstana) 31/28-29 edition reprint 2006 Krishnadas Ayurveda series vol.27 Choukhamba Krishndas Academy p.296.

18. Saxena N. Vangsena Samhita of Chikitsa Samghrah of vangasena, chaowkhamba Krishnadas academy Varanasi 2004 vol II 67/41; First edition p 805.

19. Hexal D.et.al Epidemiology of melasma in Brazilian patients: a multicenter study,International journal of Dermatology Volume 53, Issue4, 22 August 2013

20. Khalifa E. et al. Lactic Acid as a New Therapeutic Peeling Agent in Melasma, First published: F e bruary 2005 D O : $10.1111 /$ j.1524-4725.2005.31035 Volume 31, Issue 2February 2005 Pages 149-154.

21. Neel P. et.al Research Article Cosmetic Contact Sensitivity in Patients with Melasma: Results of a Pilot Study Dermatology Research and Practice 2014(12) · July 2014 with 112 Reads DOI: $10.1155 / 2014 / 316219$

22. Ida Duarte et.al Frequency of dermatoses associated with cosmetics, contact Dermatitis, Vol 56, Issue4. April 2007, Pages-211-213

23. Sorrel Resanik MC, Melasma Induced by Oral Contraceptive Drugs JAMA. 1967;199(9):601-605. doi:10.1001/jama.1967.03120090043007

24. T. Passeron. Melasma pathogenesis and influencing factors - an overview of the latest research, Journal of the European Academy of Dermatology and Venereology.

25. Vagbhtacharya, suratnojjvala, Sastri kaviraj Ambikadatta ed. Rasaratna Samuchchya 25/5 Haridas sanskrit series 91 chaukhmba oriental publishers Varanasi p.521.26.

26. Bapalal G. Vaidya ed Nighantu Adarsa (vol 2) 332 chaukhambha bharti academy Varanasi 2009 pp.16 -22 . 